\title{
Intravital assessment of body composition of cows in various production periods using urea dilution procedures
}

\author{
Maciej Adamski \\ Institute of Animal Breeding, Wroclaw University of Environmental and Life Sciences, Poland
}

\begin{abstract}
Changes in the body condition of cows are directly linked with changes in body weight and composition, and also influence their health status and productivity. In order to assess body composition, an urea dilution method was used. The method depends on the calculation of urea space resulting from differences in urea concentrations in blood before and after the infusion of the urea solution. The method is quick, not dangerous for animals and the analyses are relatively simple. The aim of this study was an attempt of an assessment of body composition of cows in the range of protein, lipid and water content in various production stages with changing condition. The research was conducted on 24 cows divided into three groups: beginning of lactation, middle of lactation, end of lactation. The present study confirmed the thesis that various production stages are accompanied by changes in body composition and condition of the cows and the changes may be determined with a high accuracy using urea method.
\end{abstract}

Keywords: body composition, lactation phase, body condition score (BCS), urea space, dairy cows

Abbreviations: BCS: body condition score, BW: body weight, CP: crude protein, DM: dry matter, EBW: empty body weight, Lip: lipids, NEL: net energy content for lactation, US: urea space, W: water 


\section{Introduction}

A systematic control of energy reserves in order to control feeding correctness in herds of high-yielding dairy cows has become an essential issue. Changes in cows' body condition influence their health status and performance (Gearhart et al. 1990, Heuer et al. 1999, Bouška et.al. 2008, Jílek et al. 2008), and are connected with changes in body weight and chemical composition as well. Degree of fulfilment of nutritional requirements may be determined using condition and also analysis of the level of selected biochemical parameters of blood. An assessment of animals' body structure is a problematical issue and it is not always possible to conduct a post-slaughter analysis. Thus, an introduction of in vivo methods has become necessary. It enables to analyse the changes in animal body in the significant productive period. An ability of an assessment of animal's body composition is a basic tool in an optimisation of meat contribution in carcass via genetic or nutritional manipulation of animal structure (De Campeneere et al. 2000).

On the current stage of research, dilution techniques based on a constant relation between ratios of water content in fat-free meat provide promising accuracy and reliability which both are required by scientists (Velazco et al. 1997, Kohn et al. 2005, Hanna 2010). The mentioned techniques include infusion techniques with deuterium (D2O, heavy hydrogen), tritiated water (T2O; marked hydrogen isotope), urea or Evans blue (De Campeneere et al. 2000). The method with urea infusion application satisfies conditions important not only for an industry but also for scientific research. Urea seems to be a good marker for an assessment of animals' body composition. Due to practical reasons however, it is more often analysed in milk than in blood (Butler et al. 1996, Richardt et al. 2001, Richardt et al. 2002). The level of that metabolite in blood is a main index reflecting nutritional status of an organism and is strictly connected to urea content in other body fluids. It is a substance that quickly diffuses to water in the whole organism. The method of urea determination is quick, does not pose any danger for an animal and it is quite simple to conduct the analysis. Also no side effects connected to its repeated application were found. It is a less time consuming method compared to that with deuterium, and additionally, properly reflects the value of cattle originating from different herds. Agnew et al. (2005) conducted the study on 104 dairy cows, which were then subjected to slaughter. They verified the data obtained after an application of the dilution method in the animal carcass using laboratory analyses. The studies confirmed the relationship between the actual body composition and those assessed using urea dilution method. Additional parameters, except the body weight, used in further calculations were milk yield and body condition score (BCS) (Bartle et al. 1983, Agnew et al. 2005). The authors demonstrated the relationship between urea space and body weight of live animals and a validity of these two parameters combining in order to assess animals' body composition.

The aim of the study was an attempt of an assessment of a composition of cows' body in the range of protein, lipids and water content with changing conditions. 


\section{Material and methods}

\section{Experimental design and treatments}

The experimental part of the study was conducted in a stanchion, litter barn maintaining in total 167 cows of Polish Holstein-Friesian breed of Black-White variety with a mean yield of over $8000 \mathrm{~kg} /$ lactation. Animal feeding was based on a traditional group system with a division on the two groups: lactating cows and dry ones. The basis of the feeding dose was maize silage and hay-silage. Diets were balanced using the DLG system, which is a modern system established in 1997 by German Agricultural Society (DLG) enabling balancing of energy and nutrients for high-yielding cows. Diet for milking cows was as follows: $15.06 \mathrm{~kg}$ DM, 98.1 MJ NEL, and $2135 \mathrm{~g}$ of total protein available in small intestine, while that for dry cows was $10.88 \mathrm{~kg} \mathrm{DM}, 51.84 \mathrm{MJ}$ NEL and $1121 \mathrm{~g}$ of total protein available in small intestine. High-yielding cows were also fed a calcium supplement against postpartum stasis (Calbal) and propylene glycol against subclinical symptoms of ketosis.

The study was conducted on 24 cows divided into three groups depending on their lactation phase. The cows were after the 2 nd and 3 rd calving. The first group included cows after calving - I phase of lactation, the second group included the cows in the middle of lactation - II phase of lactation, while the third group were cows at the end of lactation - III phase of lactation. Due to foetus safety, dry cows were not included in the study. The samples for analysis were collected at 30 day and 60 day of lactation (phase I), at 150 day, 180 day (phase II) and after 300 day of lactation (phase III). The experiment was conducted under an approval of the 2nd Local Animal Ethics Committee, Wroclaw University of Environmental and Life Sciences (no 20/06).

\section{Experiment schedule}

The sequence of the experiment was as follows:

1. Weighting of cows and an assessment of their body condition.

2. Determination of empty body weight.

3. Preparation of $20 \%$ urea solution in physiological saline.

4. Blood collection from external cervical vein before an infusion.

5. Intravenous administration of urea solution in a form of a drip.

6. Repeated collection of blood after 12 minutes from infusion.

7. An assessment of urea level in blood serum using spectrophotometric method with wavelength of $600 \mathrm{~nm}$ (Bartle et al. 1983).

The experiment was repeated after 30 days with the same procedures within each phase of lactation.

\section{Body condition and urea space determination}

Body condition was assessed according to five points scale of Wildman et al. (1982), respecting intermediate notes of 0.25 points. The condition was divided as follows: poor (BCS $\leq 3$ points), optimal (BCS 3.25-3.75 points) and very good condition = fatty cows (BCS $\geq 4$ points).

Urea dilution method was used in order to determine the contribution of protein, lipid and water content in animals. The method relies on the calculation of urea space (US) resulting 
from differences in urea concentration in blood before and after urea infusion. Volume of an infusion is calculated to supply $130 \mathrm{mg}$ of urea per $1 \mathrm{~kg}$ of body weight. Blood samples were collected $12 \mathrm{~min}$ after urea infusion. The study by Preston \& Kock (1973) conducted on dairy cattle demonstrated that urea concentration in an organism is balanced just about 9-10 min after the infusion. The analyses were focused only on urea concentration in blood; milk composition was not examined. Blood samples were usually collected $12 \mathrm{~min}$ after solution application, since that is the moment of the highest correlation between urea space and body composition of a live animal.

Urea space was calculated as the percentage of body weight (BW) according to the following formula (Bartle et al. 1983):

$$
U S(\%)=\frac{V}{V P U S \times B W}
$$

where $V$ is the infusion volume in $\mathrm{mg}, \triangle P U S(\mathrm{mg} / \mathrm{dl})$ is the difference between urea content in blood before and after infusion and $B W$ is the body weight.

Empty body weight (EBW), amount of protein, lipids and water was calculated according to the following formulas (Agnew et al. 2005):

$$
\begin{aligned}
& E B W=0.133 \times U S(\mathrm{~kg})+0.687 \times B W=21.0 \\
& C P=0.157 \times U S(\mathrm{~kg})+28.7 \\
& L i p=-0.065 \times U S(\mathrm{~kg})+0.184 \times B W-15.2 \\
& W=0.111 \times U S(\mathrm{~kg})+0.33 \times B W+42.1
\end{aligned}
$$

where $U S$ is the urea space, $C P$ is the crude protein, $L i p$ are the lipids, $W$ is the water and $B W$ is the body weight.

\section{Statistical analysis}

The results of analysis conducted were subjected to statistical analysis (Statistica 8.0, StatSoft Inc., Tulsa, OK, USA) in order to determine the level of selected parameters characteristic for the herd and their changes within the period of one month. The following parameters were calculated: means, standard deviations, medians, and after that the differences in parameters values were calculated ( $B C S$, Lip, $C P, \mathrm{H}_{2} \mathrm{O}, \mathrm{EBW}$ ) between the first and second sampling. The distributions were prepared based on these differences. The values of BCS, Lip, CP, $\mathrm{H}_{2} \mathrm{O}$, EBW were calculated based on the relationships noted by Agnew et al. (2005).

\section{Results and discussion}

Body condition of cows was differentiated in particular phases of production cycle. Especially in the case of high-yielding animals that situation reflects different requirements of an organism on energy and nutrients and points its health status (Markusfeld 1997).

Tables 1 and 2 present values of BW, BCS, US, content of water, protein and adipose tissue and their means. All the parameters were calculated twice in the same herd. 
Table 1

The values of the parameters examined for the first sampling

\begin{tabular}{lcccc}
\hline & Mean & SD & Min & Max \\
\hline BCS & 3.32 & 0.74 & 2.00 & 4.75 \\
BW, kg & 591.0 & 90.7 & 410.0 & 750.0 \\
EBW, kg & 422.8 & 70.5 & 285.2 & 544.8 \\
US, g/kgEBW & 667.3 & 58.7 & 539.3 & 748.6 \\
$\mathrm{H}_{2} \mathrm{O}, \mathrm{kg}$ & 268.7 & 36.8 & 197.8 & 331.8 \\
CP, g/kgEBW & 183.3 & 3.1 & 178.8 & 191.8 \\
Lip, g/kgEBW & 116.2 & 18.4 & 64.0 & 143.0 \\
\hline
\end{tabular}

SD: standard deviation, $\mathrm{g} / \mathrm{kgEBW}$ : amount of grams for $1 \mathrm{~kg}$ of empty body weight,

Table 2

The values of the parameters examined for the second sampling

\begin{tabular}{lcccc}
\hline & Mean & SD & Min & Max \\
\hline BCS & 3.30 & 0.71 & 1.75 & 4.75 \\
BW, kg & 592.7 & 81.7 & 405.0 & 750.0 \\
EBW, kg & 425.2 & 63.0 & 282.4 & 543.2 \\
US, g/kgEBW & 686.7 & 77.2 & 563.0 & 838.9 \\
$\mathrm{H}_{2} \mathrm{O}, \mathrm{kg}$ & 270.3 & 32.8 & 196.8 & 330.7 \\
CP, g/kgEBW & 183.3 & 3.0 & 178.6 & 192.4 \\
Lip, g/kgEBW & 113.5 & 21.9 & 55.8 & 144.9 \\
\hline
\end{tabular}

Table 3 presents differences of mean values for above parameters, and also calculated median of differences.

Table 3

Changes of analysed parameters

\begin{tabular}{lccc}
\hline Difference & Min & Max & Median \\
\hline BCS2-BCS1 & -1.00 & 0.75 & 0.00 \\
BW2-BW1, kg & -52.00 & 63.00 & 5.50 \\
EBW2-EBW1, kg & -34.93 & 50.98 & 3.97 \\
Lip2-Lip1, g/kgEBW & -27.66 & 12.24 & 1.68 \\
CP2-CP1, g/kgEBW & -2.10 & 2.47 & -0.26 \\
H_O_2-H_O_1, kg & -16.49 & 27.22 & 2.22 \\
\hline
\end{tabular}

The level of condition was changed in the case of $71 \%$ of individuals during the time between subsequent analyses. Increasing tendency in body condition was observed in the biggest number of cows $-41.6 \%$, and that was III lactation phase, while in the case of $29.2 \%$ of cows the condition decreased at I phase of lactation. At the same time $29.2 \%$ of cows did not show any condition changes between the assessments at II phase of lactation (Figure 1).

Analyses of mean values of the examined parameters demonstrated some slight changes (Table 3). The most distinct differences were noted for body weight, water and lipids in various production cycles. No statistically significant changes between mean values of parameters in the two different samplings were observed when using ANOVA test.

The values of analysed parameter differences and their medians depending on production period are presented in Tables 4, 5 and 6. 
Table 4

Values of differences of parameters and their medians for cows at I phase of lactation whose BCS decreased

\begin{tabular}{lccccc}
\hline No of cow & BCS2-BCS1 & $\begin{array}{c}\text { Lip2-Lip1, } \\
\text { g/kgEBW }\end{array}$ & $\begin{array}{c}\text { BCS decrease } \\
\text { CP2-CP1, } \\
\text { g/kgEBW }\end{array}$ & $\begin{array}{c}\mathrm{H}_{2} \mathrm{O} \_2- \\
\mathrm{H}_{2} \mathrm{O}-1, \mathrm{~kg}\end{array}$ & $\begin{array}{c}\text { EBW2-EBW, } \\
\mathrm{kg}\end{array}$ \\
\hline 4 & -0.25 & -8.24 & 0.66 & -1.08 & -2.76 \\
5 & -0.25 & -27.66 & 2.47 & -6.33 & -15.46 \\
10 & -0.25 & -10.11 & 1.10 & -6.82 & -14.29 \\
14 & -0.50 & -15.33 & 1.75 & -10.54 & -22.55 \\
19 & -1.00 & -19.89 & 2.23 & -16.49 & -34.93 \\
21 & -0.50 & -26.11 & 2.90 & -15.07 & -32.35 \\
22 & -1.00 & -18.75 & 2.09 & -14.73 & -31.36 \\
Median & -0.50 & -18.75 & 2.09 & -10.54 & -22.55 \\
\hline
\end{tabular}

Table 5

Values of differences of parameters and their medians for cows at II phase of lactation whose BCS did not change

\begin{tabular}{lccccc}
\hline No of cow & BCS2-BCS1 & $\begin{array}{c}\text { Lip2-Lip1, } \\
\text { g/kgEBW }\end{array}$ & $\begin{array}{c}\text { BCS not changed } \\
\text { CP2-CP1, } \\
\text { g/kgEBW }\end{array}$ & $\begin{array}{r}\mathrm{H}_{2} \mathrm{O} \_2- \\
\mathrm{H}_{2} \mathrm{O}-1, \mathrm{~kg}\end{array}$ & $\begin{array}{c}\text { EBW2-EBW1, } \\
\mathrm{kg}\end{array}$ \\
\hline 6 & 0.00 & -3.83 & 0.23 & 1.91 & 2.88 \\
9 & 0.00 & 3.48 & -0.45 & 3.94 & 7.93 \\
13 & 0.00 & 2.26 & -0.29 & 2.52 & 5.06 \\
15 & 0.00 & -2.19 & 0.25 & -1.55 & -3.32 \\
17 & 0.00 & -1.63 & 0.19 & -1.05 & -2.43 \\
18 & 0.00 & 1.94 & -0.22 & 0.90 & 2.24 \\
24 & 0.00 & 0.39 & -0.04 & 0.33 & 0.69 \\
Median & 0.00 & 0.39 & -0.04 & 0.90 & 2.24 \\
\hline
\end{tabular}

Table 6

Values of differences of parameters and their medians for cows at III phase of lactation whose BCS increased

\begin{tabular}{lccccc}
\hline No of cow & $\begin{array}{c}\text { BCS2-BC } \\
\mathrm{S} 1\end{array}$ & $\begin{array}{c}\text { Lip2-Lip, } \\
\mathrm{g} / \mathrm{kgEBW}\end{array}$ & $\begin{array}{c}\text { BCS increase } \\
\mathrm{CP2}-\mathrm{CP1}, \\
\mathrm{g} / \mathrm{kgEBW}\end{array}$ & $\begin{array}{c}\mathrm{H}_{2} \mathrm{O}_{2} 2-\mathrm{H}_{2} \mathrm{O}{ }_{-} 1, \\
\mathrm{~kg}\end{array}$ & $\begin{array}{c}\text { EBW2-EBW1, } \\
\mathrm{kg}\end{array}$ \\
\hline 1 & 0.25 & 6.22 & -1.34 & 9.94 & 19.20 \\
2 & 0.25 & 1.41 & -0.55 & 6.28 & 11.89 \\
3 & 0.25 & 3.40 & -0.78 & 7.59 & 14.63 \\
7 & 0.25 & 6.99 & -1.03 & 7.93 & 15.62 \\
8 & 0.75 & 4.80 & -2.10 & 27.22 & 50.98 \\
11 & 0.50 & 5.99 & -1.04 & 13.81 & 43.93 \\
12 & 0.25 & 12.24 & -1.63 & 13.34 & 26.78 \\
16 & 0.25 & 11.90 & 0.46 & 3.81 & 16.98 \\
20 & 0.25 & 2.31 & -0.40 & 5.99 & 11.56 \\
23 & 0.25 & 5.39 & -0.69 & 7.84 & 15.81 \\
Median & 0.25 & 5.69 & -0.91 & 7.88 & 16.39 \\
\hline
\end{tabular}

Rapid condition decrease and body weight loss were observed in cows after calving, i.e. at I phase of lactation (Table 4). Mean level of losses for empty body weight was $22.55 \mathrm{~kg}$, however the calculated losses were even as high as $35 \mathrm{~kg}$. Also, a decrease in lipid and water content on an average level of $18.75 \mathrm{~g} / \mathrm{kg}$ EBW and $10.54 \mathrm{~g} / \mathrm{kg} \mathrm{EBW}$, respectively was noted. 
In the case of protein content in turn, the minimum increase on an average level of $2.09 \mathrm{~g} /$ $\mathrm{kg}$ EBW was observed. In the period when the cows entering the middle phase of lactation (II phase) their condition was maintained on the same level. Very small changes in the range of the analysed body composition parameters were noted (Table 5). At III phase of lactation, the restoration of energy reserves of cows was accompanied by an increase in body condition on an average level of 0.25 pts (Table 6). The mean increase calculated in this period in empty body weight was amounted to $16.39 \mathrm{~kg}$, lipids $5.69 \mathrm{~g} / \mathrm{kg}$ EBW, and water $7.88 \mathrm{~kg}$. However, the noted decrease in protein content was on a small level, below one gram, i.e. $-0.91 \mathrm{~g} / \mathrm{kg}$ EBW.

The distribution of differences between the samplings for the assessed parameters of body composition (in empty body weight), irrespectively from the phase of lactation, are presented on Figures 1 to 6 .

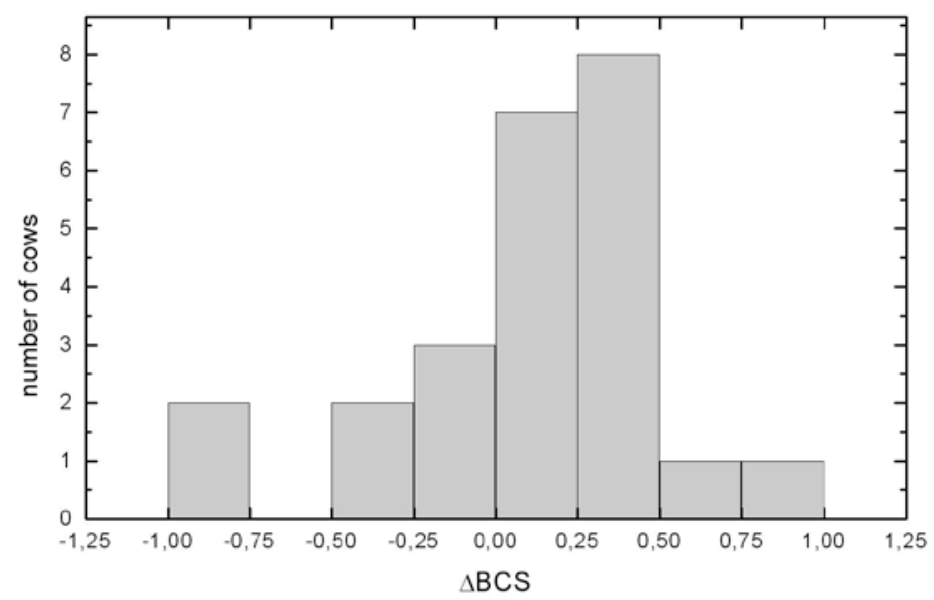

Figure 1

Distribution of differences $\triangle B C S=B C S 2-B C S 1$ (BCS2: BCS level at second sampling, BCS1: BCS level at first sampling)

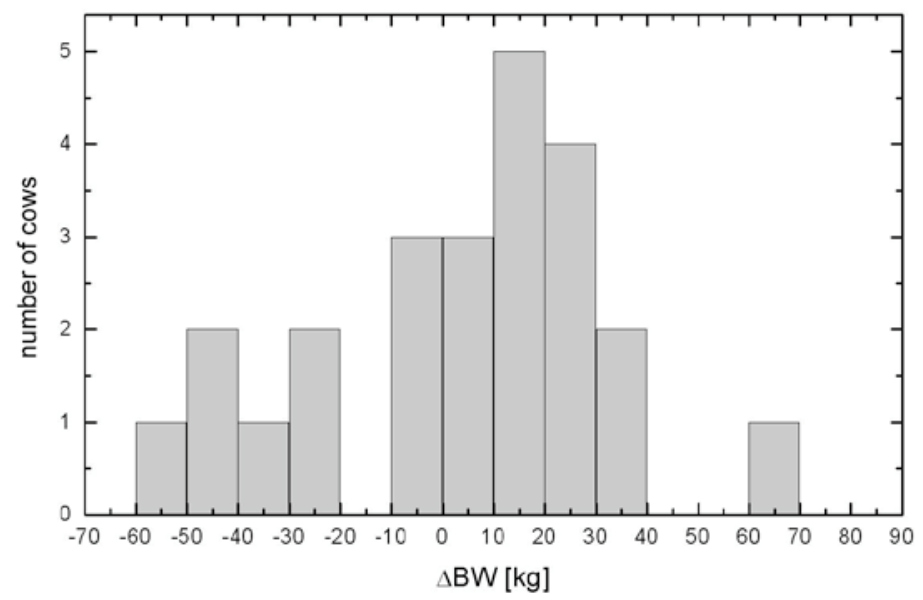

Figure 2

Distribution of differences $\triangle B W=B W 2-B W 1$ (BW2: body weight at second sampling, BW1: body weight at first sampling) 


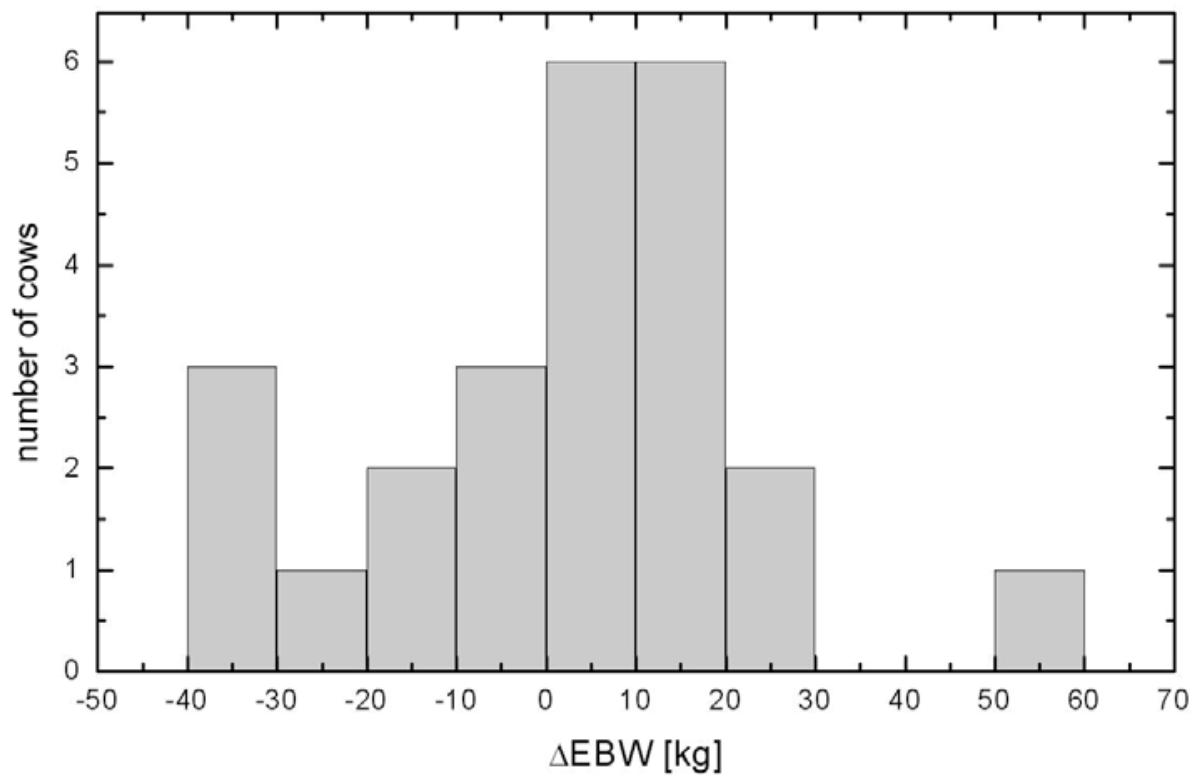

Figure 3

Distribution of differences $\triangle E B W=E B W 2-E B W 1$ (EBW2: empty body weight at second sampling, EBW1: empty body weight at first sampling)

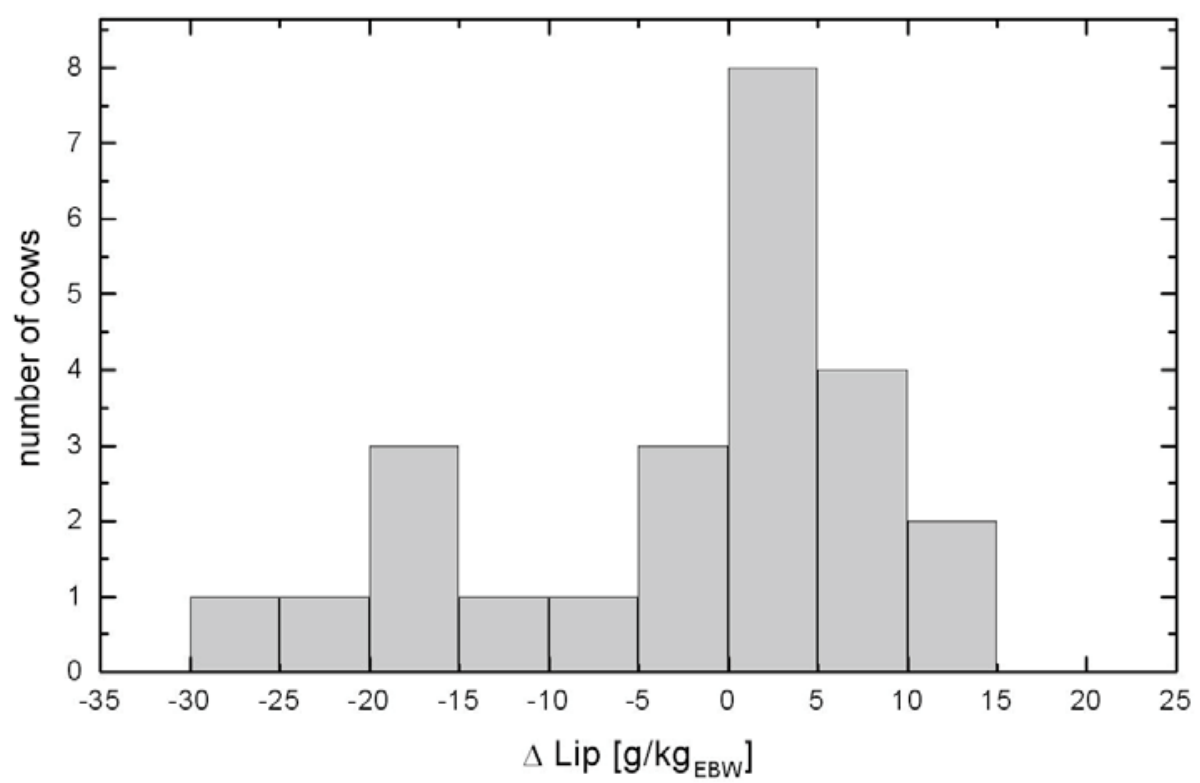

Figure 4

Distribution of differences $\Delta$ Lip=Lip2-Lip2 (Lip2: lipids level at second sampling, Lip1: lipids level at first sampling) in grams for $1 \mathrm{~kg}$ of empty body weight 


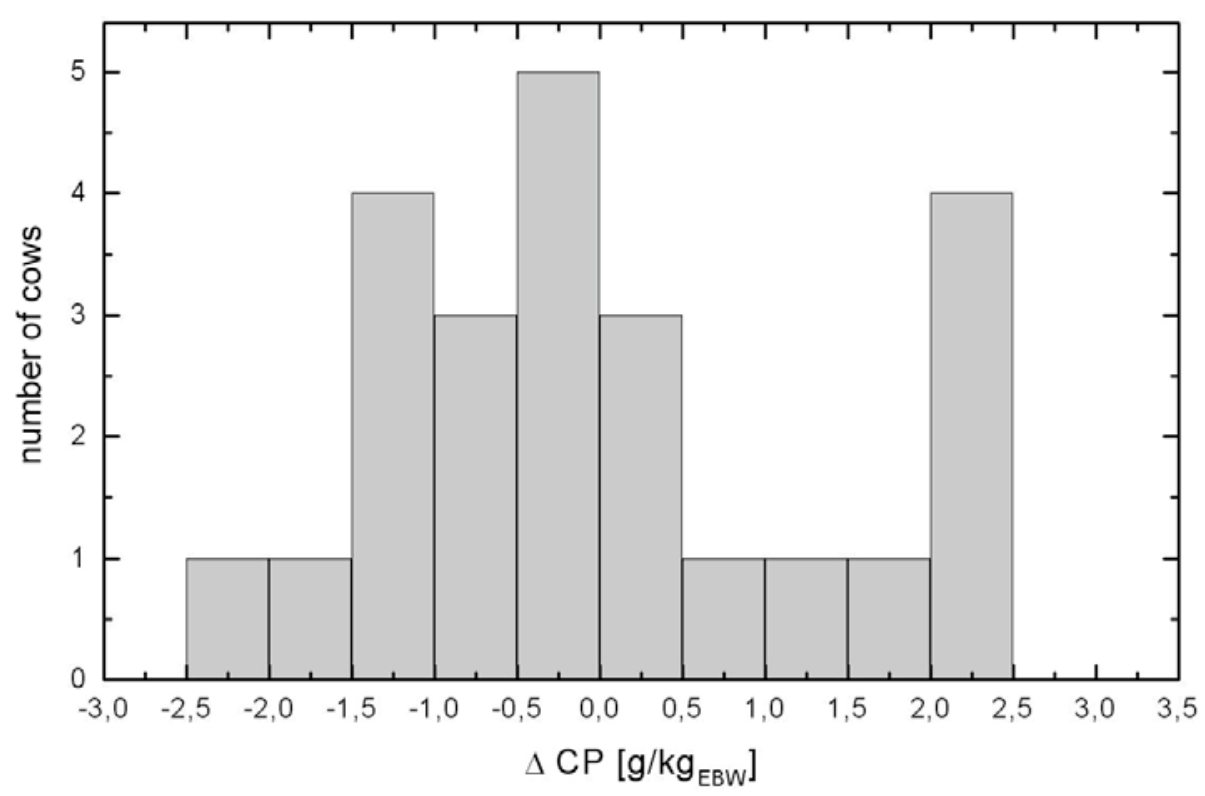

Figure 5

Distribution of differences $\triangle C P=C P 2-C P 2$ (CP2: protein level at second sampling, $C P 1$ : protein level at first sampling) in grams for $1 \mathrm{~kg}$ of empty body weight

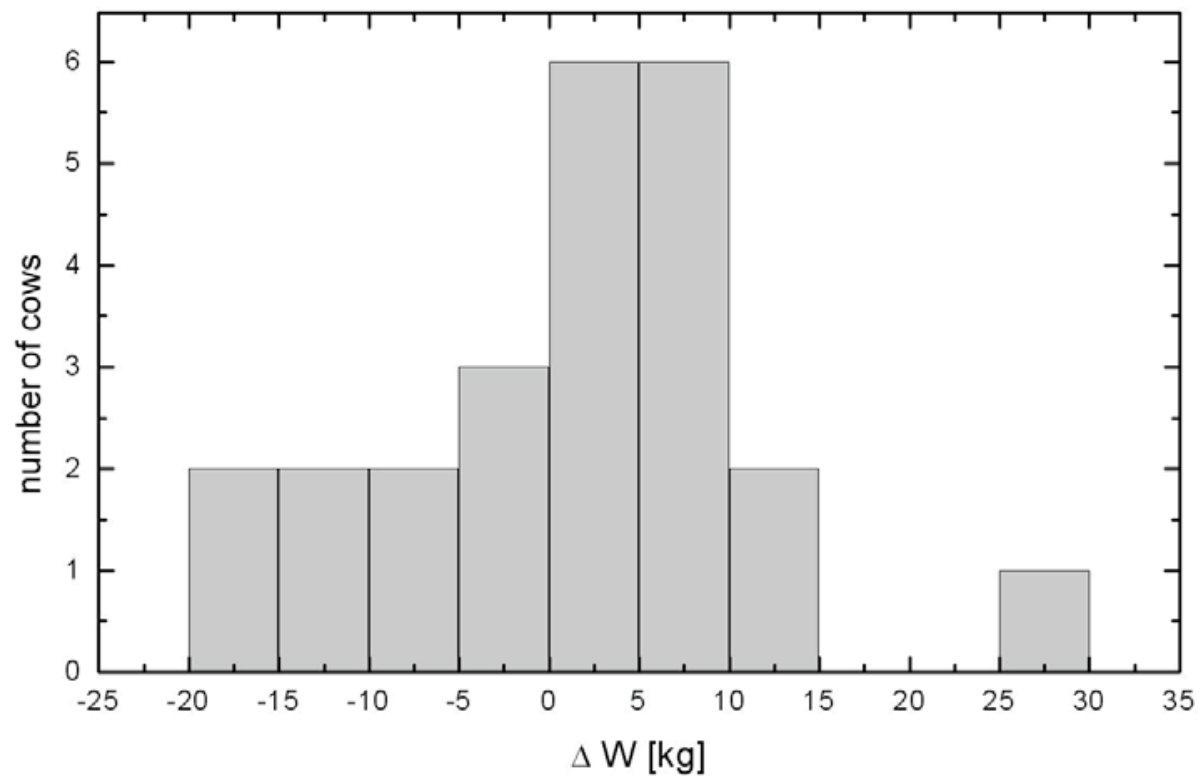

Figure 6

Distribution of differences $\Delta \mathrm{W}=\mathrm{W} 2-\mathrm{W} 2$ (W2: water level at second sampling, W1: water level at first sampling) 
Lack of changes in body fat content was noted for $45.8 \%$ of cows, in the case of $25 \%$ an increase was observed, while a decrease was noted in $29.2 \%$ of cows. The changes in crude protein level were as follows: lack of differences in $33.3 \%$, increase in $29.2 \%$ and a decrease in $37.5 \%$ of cows. In most of the analysed cows the content of protein did not changed significantly. The content of water calculated in cows body was as follows: lack of changes in $37.5 \%$ of cows, increase also in $37.5 \%$ of the animals and decrease in $25 \%$ of cows. Concurrently with the observed decrease in cows' body condition, also a decrease in adipose tissue level was noted and its increase with condition improvement respectively. Negligible changes in condition and other parameters determined may result from the too short time interval between the subsequent samplings.

The usefulness of urea dilution method in an assessment of body composition of high fat breed cows was analysed by Velazco et al. (1997). The authors calculated correlation coefficients for following components: water content $(0.66 ; 0.79 ; 0.79)$, lipids $(0.57 ; 0.62$; $0.62)$ and protein $(0.65 ; 0.51 ; 0.76)$. The older the animals were, the lower was the precision of an assessment of carcass composition. The results of previous studies point the significant $(P \leq 0.01)$ relationships between body weight of animals and the value of US (Bartle et al. 1987, Agnew et al. 2005, Hanna 2010). Urea space value increased with an increase in body weight. In the case of the heaviest cow $(754 \mathrm{~kg})$ and those of the highest condition (4.75 points), the following body composition was calculated: protein $97.85 \mathrm{~kg}$, lipids $98.83 \mathrm{~kg}$ and water $333.11 \mathrm{~kg}$. The results of the present study are confirmed in the studies of Bartle et al. (1983, 1987) and Agnew et al. (2005). They had the possibility of a verification of the data obtained using urea dilution method in a laboratory study conducted on carcasses of experimental animals. The changes of the production level, physiology and condition were reflected in the changes of the body composition of dairy cows, especially in the case of lipid content.

The change in dairy cows' adiposity level is a factor influencing their health status and performance. These changes are connected not only with body weight changes, but also with changes in the body's chemical composition. The degree of nutritional requirements fulfilment may be determined based on body condition assessment, and also by analysis of the level of selected biochemical indices of blood, including urea. The study conducted suggests that the changes of lactation stage, body weight and condition are accompanied by the changes of the body composition. The most important finding which was also confirmed in the present study is the changing in adiposity level. It was observed in the study conducted by Hanna (2010) that water percentage in cattle body was significantly correlated with urea space at 12 min as percentages to BW or EBW. The authors concluded that the leaner animals, urea equilibrated faster with body water compared to fatter animals, which may explain an occurrence of maximum values of correlation at different times after infusion in various animal species. It allows the breeder to plan and improve the production cycle in dairy cow herds in a proper manner. Too high fat level during the last lactation stage and dry period may result in a lower production level, low calving rate index, difficult parturitions and chronic metabolic diseases. The control and correction of adiposity level in animals allow avoiding these problems to a considerable degree.

Based on the studies conducted by numerous authors, and the results obtained in the present study as well, the usefulness of US using in calculation of animals' body composition may be stated, however the calculations based on live animal are more precise and US may be 
a supporting value. Wells \& Preston (1998) conducted the study concerning the relationship of repeated urea dilution measurements with body condition in steers of different breeds and they concluded that the procedure of urea dilution did not affect parameters like daily gain, dry matter intake or empty carcass fat. Thus, the urea dilution may be a valuable research tool where multiple analyses of body composition could be required over time without the condition of animal slaughtering. This means that the urea dilution method; and urea space itself as a variable determining the content of protein, lipids and water in an organism; is reasonable in dairy cow herds. At the same time, an assessment of body condition facilitates the qualitative determination of adiposity level in cows. This is of considerable significance in an assessment of planned milk production. It also indirectly informs of the health status and possible reproduction parameters.

\section{References}

Agnew RE, Yan T, McCaughey WJ, McEvoy JD, Patterson DC, Porter MG, Steen RWJ (2005) Relationships Between Urea Dilution Measurements and Body Weight and Composition of Lactating Dairy Cows. J Dairy Sci 88, 2476-2486

Bartle SJ, Kock SW, Preston RL, Wheeler TL, Davis GW (1987) Validation of Urea Dilution to Estimate In Vivo Body Composition in Cattle. J Anim Sci 64, 1024-1030

Bartle SJ, Males JR, Preston RL (1983) Evaluation of Urea Dilution as an Estimator of Body Composition in Mature Cows. J Anim Sci 56, 410-417

Bouška J, Štípková M, Pytloun P, Pytloun J, Kubešová M (2008) Relationships among body condition score, milk yield and sires' breeding value for beef production efficiency in Czech Fleckvieh cattle. Czech J Anim Sci 53, 453-461

Butler WR, Calaman JJ, Beam SW (1996) Plasma and milk urea nitrogen in relation to pregnancy rate in lactating dairy cattle. J Anim Sci 74, 858-865

De Campeneere S, Fiems L, Boucqué C (2000) In vivo estimation of body composition in cattle. Nutr Abstr Rev B 70, 495-508

Gearhart MA, Curtis CR, Erb HN, Smith RD, Sniffen CJ, Chase LE, Cooper MD (1990) Relationship of Changes in Condition Score to Cow Health in Holsteins. J Dairy Sci 73, 3132-3140

Hanna SS (2010) Estimation of Carcass Composition of Sheep, Goats and Cattle by the Urea Dilution Technique. Pak J Nutr 9, 1107-1112

Heuer C, Schukken YH, Dobbelaar P (1999) Postpartum Body Condition Score and Results from the First Test Day Milk as Predictors of Disease, Fertility, Yield, and Culling in Commercial Dairy Herds. J Dairy Sci 82, 295-304

Jílek F, Pytloun P, Kubešová M, Štípková M, Bouška J, Volek J, Frelich J, Rajmon R (2008) Relationships among body condition score, milk yield and reproduction in Czech Fleckvieh cows. Czech J Anim Sci 53, 357-367

Kohn RA, Dinneen MM, Russek-Cohen E (2005) Using blood urea nitrogen to predict nitrogen excretion and efficiency of nitrogen utilization in cattle, sheep, goats, horses, pigs, and rats. J Anim Sci 83, 879-889

Markusfeld O, Galon N, Ezra E (1997) Body condition score, health, yield and fertility in dairy cows. Vet Rec $141,67-72$

Preston RL, Kock SW (1973) In vivo prediction of body composition to energy intake and energetic. J Dairy Sci 12, 1344-1359

Richardt W, Jeroch H, Spilke J (2001) [The impact of nutrition and non nutrition factors on milk urea concentration. II. The impact of non nutrition factors on milk urea concentration]. Arch Tierz 44, 505-519 [in German] 
Richardt W, Jeroch H, Spilke J (2002) [The impact of nutrition and non nutrition factors on milk urea concentration. III. A new milk urea model to indicate the dietary crude protein/energy balance in dairy cows]. Arch Tierz 45, 151-157 [in German]

Velazco J, Morrill JL, Kropf DH, Brandt Jr RT, Harmon DL, Preston RL, Clarenburg R (1997) The use of urea dilution for estimation of carcass composition of Holstein steers at 3, 6, 9, and 12 months of age. J Anim Sci 75, 139-147

Wells RS, Preston RL (1998) Effects of repeated urea dilution measurement on feedlot performance and consistency of estimated body composition in steers of different breed types. J Anim Sci 76, 2799-2804

Wildman EE, Jones GM, Wagner PE, Boman RL, Troutt Jr HF, Lesch TN (1982) A Dairy Cow Body Condition Scoring System and Its Relationship to Selected Production Characteristics. J Dairy Sci 65, 495-501 